\title{
The specifics of formation of the loyalty strategy in the field of alternative energy
}

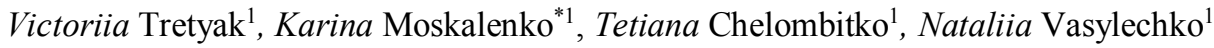 \\ ${ }^{1}$ V. N. Karazin Kharkiv National University, 4 Svobody Sq., Kharkiv, 61022, Ukraine
}

\begin{abstract}
The essence of the definitions of "strategy", "loyalty" and "loyalty strategy" is considered, and the peculiar vision of the definition "loyalty strategy in the field of alternative energy" is proposed. The specifics of formation of the loyalty strategy in the field of alternative energy are determined. The stages of formation of the loyalty strategy for stakeholders in the field of alternative energy are grouped. It is proved that the branch of alternative energy has a significant impact on territorial development, in particular on the transformation of socio-economic processes in the region.
\end{abstract}

\section{Introduction}

Formation of effective governmental long-term policy requires the socio-economic development of the territories. The concept of the development of a separate region is aimed at defining tasks and tools for solving social problems, productivity of the economy, and profitability of business and income of the population [1].

Transformational processes of decentralization of the economy will help to increase the role of regions in organizing and ensuring real processes of sustainable development, mobilizing resources and funds for certain goals. Therefore, the use of alternative energy is highly relevant.

Under today's conditions of economic competition, the formation of the loyalty strategy in the field of alternative energy appears as a way of representing market participants, their values, goals and socio-ethical commitments.

The peculiarities of the development of communication management through the formation of the loyalty strategy are reflected in the publications of such scholars as I. Kliachenko [2], Yu. Kniazyk [3], K. Gurdjyian [4], D. Aaker [5], and others. However, under modern conditions of economy management, it is necessary that one should further study and improve the issue of the formation of the loyalty strategy for stakeholders in the field of alternative energy.

\section{Main Results}

\footnotetext{
${ }^{*}$ Corresponding author: kmoskalenko@karazin.ua
} 
At the core of any research lies the definition of the essence of economic categories. Therefore, within the framework of this research, we consider that special attention should be paid to studying the scientists' views on the interpretation of such concepts as: "strategy", "loyalty" and "loyalty strategy". The definitions of the term "strategy" are given in Table 1.

Table 1: The definitions of the term "strategy" [6-9].

\begin{tabular}{|c|l|l|}
\hline No. & \multicolumn{1}{|c|}{ Author } & \multicolumn{1}{c|}{ Definition } \\
\hline 1 & \multicolumn{1}{|c|}{2} & \multicolumn{1}{c|}{3} \\
\hline 1. & I. Ansoff & $\begin{array}{l}\text { Strategy is a systematic approach that ensures balance } \\
\text { and overall management of the organization [6]. }\end{array}$ \\
\hline 2. & $\begin{array}{l}\text { M. H. Meskon } \\
\text { M. Albert } \\
\text { F. Khedouri }\end{array}$ & $\begin{array}{l}\text { Strategy is a detailed and complex plan which has to } \\
\text { ensure accomplishing of the mission of the } \\
\text { organization and achieving its goals [7]. }\end{array}$ \\
\hline 3. & B. Carlof & $\begin{array}{l}\text { Strategy is a generalized model of action that is } \\
\text { needed to coordinate the company's activities and } \\
\text { allocate resources [8]. }\end{array}$ \\
\hline 4. & $\begin{array}{l}\text { T. Kalinescu } \\
\text { Yu. A. Romanovskaya, } \\
\text { O. D. Kirilov }\end{array}$ & $\begin{array}{l}\text { Strategy is a set of measures (goals, tasks and ways of } \\
\text { their accomplishment) to ensure the profitability of } \\
\text { the enterprise [9]. }\end{array}$ \\
\hline
\end{tabular}

At the time of this research, market conditions in the field of alternative energy in Ukraine are characterized by high competition among producers of goods and services in the sphere of generating energy from alternative sources, the emergence of new channels of communication between stakeholders, such as: sale of goods and services through the Internet sites and social networks of generating companies and the marketing management system of production.

Thus, in the field of alternative energy, the "buyer's market" prevails when the volume of goods or services exceeds the demand of the buyers. Therefore, the formation of loyalty of the stakeholders takes the leading place among the strategic objectives of the enterprise.

The term "loyalty" encompasses various aspects in relations between stakeholders. The definitions of the term "loyalty" are given in Table 2.

Table 2: The definitions of the term "loyalty" [5, 10, 11, 12].

\begin{tabular}{|c|l|l|}
\hline No. & \multicolumn{1}{|c|}{ Author } & \multicolumn{1}{c|}{ Definition } \\
\hline 1 & \multicolumn{1}{|c|}{2} & \multicolumn{1}{c|}{3} \\
\hline 1. & D. Aaker & $\begin{array}{l}\text { Loyalty as measure of a customer's commitment to the } \\
\text { brand. It shows the level of probability of switching to } \\
\text { another brand, especially when changes in price or any } \\
\text { other indicators take place [5]. }\end{array}$ \\
\hline 2. & J. Rossiter and L. Percy & $\begin{array}{l}\text { Loyalty as a regular (recurring) purchase of a branded } \\
\text { product based on familiarity with and favorable } \\
\text { attitude to the brand [10]. }\end{array}$ \\
\hline 3. & F. Reichhold & $\begin{array}{l}\text { Loyalty as property inherent to a user of value who } \\
\text { each time returns to his/her source and leaves this } \\
\text { source as inheritance. That means that loyalty is } \\
\text { commitment to his/her source of value [11]. }\end{array}$ \\
\hline
\end{tabular}




\begin{tabular}{|c|l|l|}
\hline 4. & F. Kotler & $\begin{array}{l}\text { Loyalty as advantage of the customer formed as a } \\
\text { result of the personification of feelings, emotions, } \\
\text { thoughts regarding an organization and services [12]. }\end{array}$ \\
\hline
\end{tabular}

At the present stage of development of economic thought, the definition of the term "loyalty strategy" has also acquired its further development. The definitions of the term "loyalty strategy" are given in Table 3.

Table 3: The definitions of the term "loyalty strategy" [2, 13, 14, 15].

\begin{tabular}{|c|l|l|}
\hline No. & \multicolumn{1}{|c|}{ Author } & \multicolumn{1}{c|}{ Definition } \\
\hline 1 & \multicolumn{1}{|c|}{2} & \multicolumn{1}{c|}{3} \\
\hline 1. & E. Taylor & $\begin{array}{l}\text { Loyalty strategy is a course of action on the basis of which a } \\
\text { company will create an advertising product or service, that } \\
\text { means that loyalty strategy under today's market conditions is } \\
\text { a guiding approach to communicating with stakeholders [13]. }\end{array}$ \\
\hline 2. & H. Mintzberg & $\begin{array}{l}\text { Loyalty strategy is a method of management to increase the } \\
\text { competitiveness of an enterprise [14]. }\end{array}$ \\
\hline 3. & Ye. Romat & $\begin{array}{l}\text { Loyalty strategy as program of integrated marketing } \\
\text { communications used to cover goods and services [15]. }\end{array}$ \\
\hline 4. & I. Kliachenko & $\begin{array}{l}\text { Loyalty strategy is a long-term program of interaction } \\
\text { between the company and its stakeholders [2]. }\end{array}$ \\
\hline
\end{tabular}

The consideration of the theoretical material enabled us to develop our own vision of the definition of "the loyalty strategy in the field of alternative energy" as program of longterm mutually beneficial relations between stakeholders, in which they can not only choose from a variety of goods or services, but also aim to expand the policy of market actors in such a way that it corresponds their interests as much as possible. The following features have to be taken into account when developing the loyalty strategy in the field of alternative energy:

- establishment of long-term relations between stakeholders which require analysis of all stages of purchase, supply, transportation, storage and consumption of energy;

- state policy in the field of alternative energy, the work of regulatory authorities;

- interests of generating companies, energy companies, end users;

- a complicated process of purchasing energy resources, which involves a wide range of individuals.

Taking into account the 0peculiarities of the alternative energy sector, we have grouped the stages of the formation of loyalty strategy for stakeholders in this area (Fig. 1). 


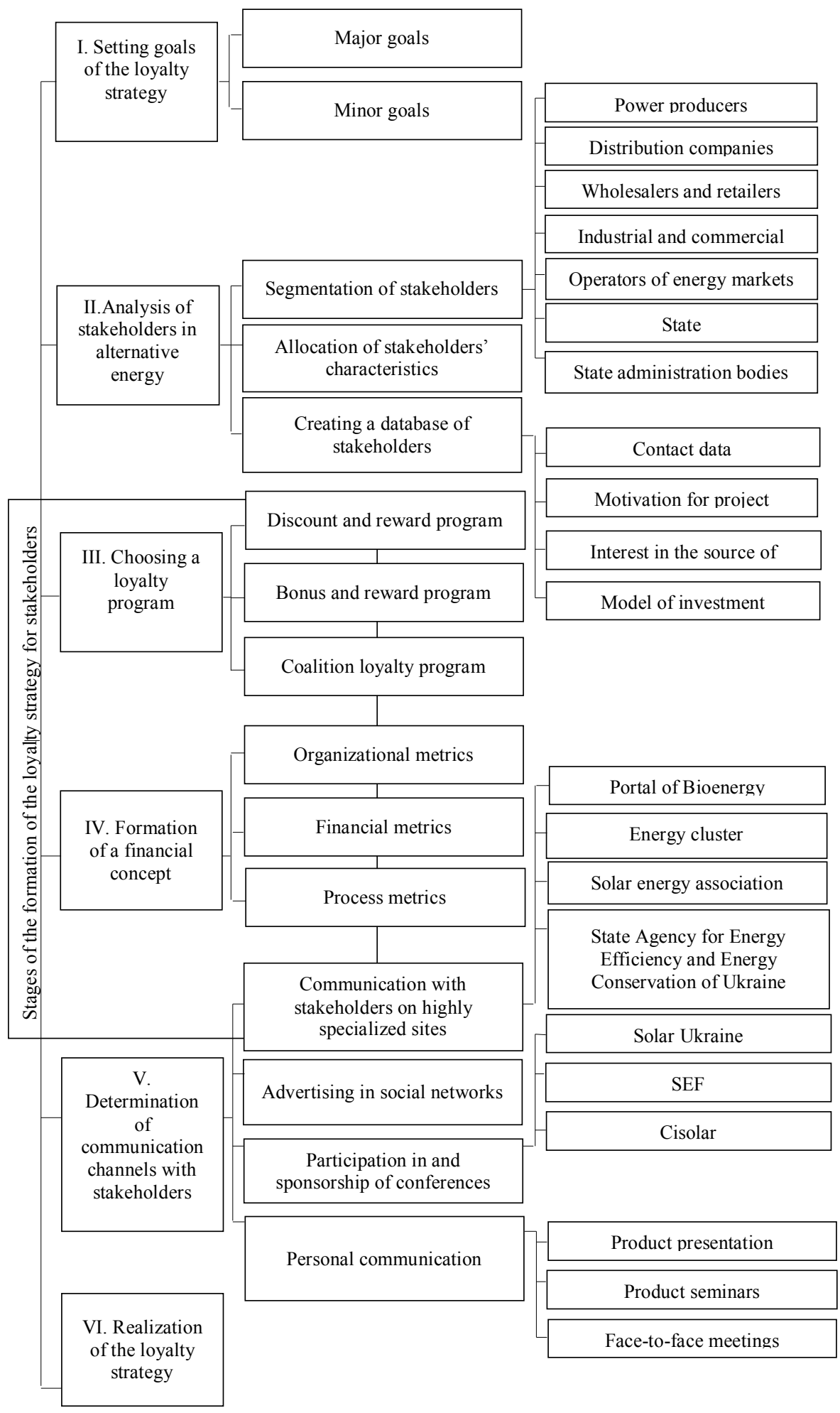

Fig. 1.Stages of the formation of loyalty strategy for stakeholders in the field of alternative energy. 
The formation of the loyalty strategy for stakeholders in the field of alternative energy is a crucial factor in territorial development, as the interest in the development of energy resources arises if stakeholders express their loyalty to the energy market. Characteristics of the impact of alternative energy introduction on the territorial development, taking into account the legislative norms on alternative energy sources [16], are presented in Figure 2.

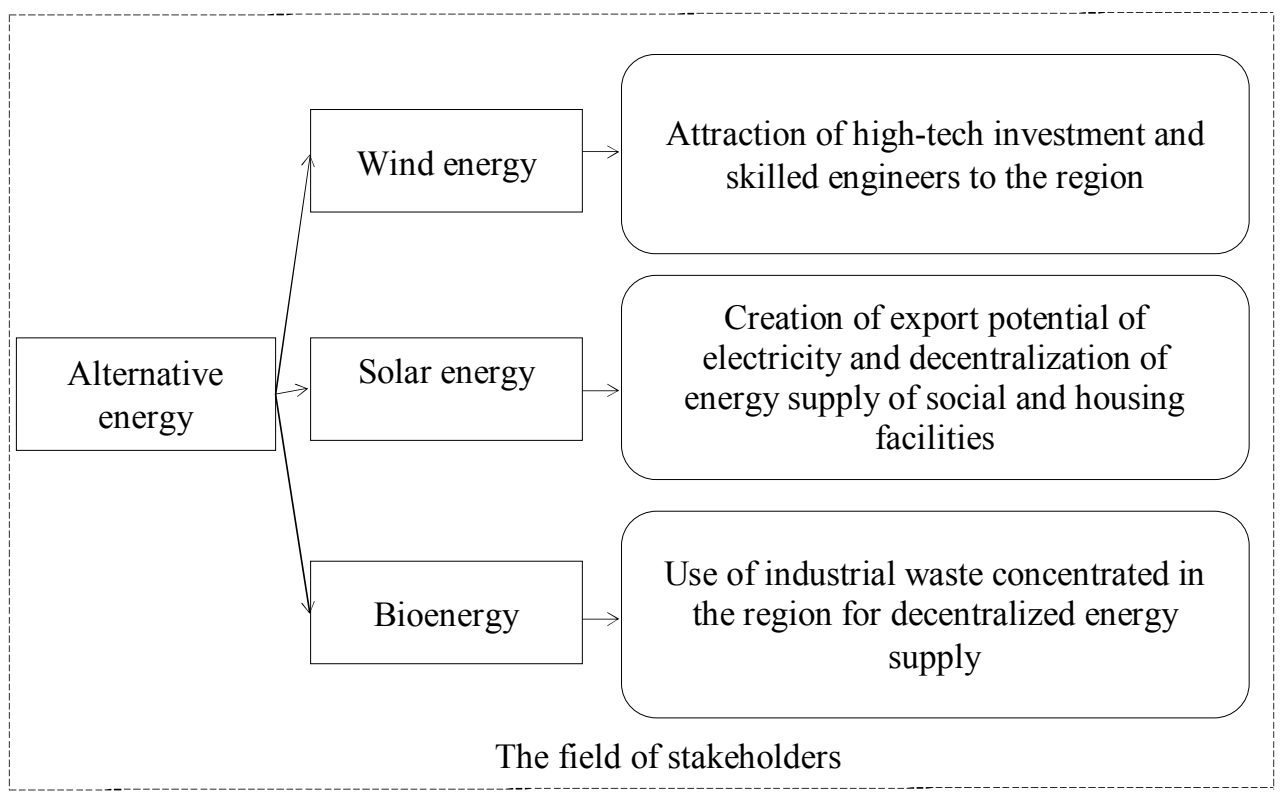

Fig. 2. The structure and characteristics of the impact of alternative energy introduction on the territorial development.

Thus, energy sources have a fairly even distribution and can be used to decentralize energy supply. This reduces the cost of energy transportation, diversifies the risks of the destruction of energy networks and if using alternative sources of energy, it brings down the use of fossil fuels, which is the basis of energy security both for separate territories and for the state as a whole.

\section{Conclusion}

The field of alternative energy has a significant impact on territorial development, in particular on the transformation of socio-economic processes in the region, i.e.: if free energy resources are available on a certain territory, potential investors express their loyalty to the implementation of new projects, thereby developing the territory (creating new generating capacities and jobs, consuming agricultural production waste, etc.). The introduction of alternative energy will promote the development of small and medium-sized businesses, as well as improve living standards.

The loyalty strategy in the field of alternative energy is a program of long-term mutually beneficial relations between stakeholders, which includes communication support with a set of incentive benefits. 


\section{References}

1. Official bulletin of Ukraine, 70, 34 (2014)

2. I. O. Klyachenko, O. V. Zozulov, Consumer Loyalty to the Brand Program, 28 (2012)

3. Y. M. Knyazyk, T. V. Lebid, Formation of consumer loyalty as one of the directions of increasing profitability of the enterprise, 86-90 (2006)

4. K. V. Gurdjian, Essence and types of loyalty, 78-86 (2015)

5. D. Aaker, Creation of strong brands, 320 (2008)

6. I. Ansoff, New corporate strategy, 416 (1999)

7. M. Meskon, M. Albert, F. Hedouri, Fundamentals of Management, 702 (1992)

8. B. Carloff, Business Strategy: Concept, Content, Symbols, 239 (1991)

9. T. V. Kalinescu, U. A. Romanovskaya, O. D Kirilov, Strategic potential of the enterprise: formation and development, 272 (2007)

10. J. Rossiter, L. Percy, Advertising and promotion of goods, 136-143 (2000)

11. Y. Skobeleva, Measuring loyalty to the brand according to the "residual promoter index" method by Frederick F. Reichheld, available at: http://www.satio.by/publications/researches/76.html

12. P. Kotler, Marketing 3.0: from products to consumers and further - to the human soul, 240 (2011)

13. R. E. Taylor, A Six-Segment Message Strategy Wheel, 7-12 (1999)

14. G. Minzberg, D. Quinn, S. Goshall, Strategic Process: Concepts, Problems, Solutions, 684 (2000)

15. E. V. Romat, Advertising, 496 (2001)

16. Data of the Verkhovna Rada of Ukraine, 24, 155 (2003) 